\title{
MANAJEMEN KRISIS PEMERINTAH KABUPATEN KULON PROGO
}

\author{
Siti Mawadati ${ }^{1}$, dan Choirul Fajri ${ }^{2}$ \\ Fakultas Sastra Budaya dan Komunikasi Universitas Ahmad Dahlan Yogyakarta \\ Jl. Pramuka 42, Sidikan, Umbulharjo, Yogyakarta 55161. Telp. (0274) 563515 \\ Email : st_mawadati@yahoo.com ${ }^{1}$, choirulfajri@yahoo.co.id ${ }^{2}$
}

\begin{abstract}
The development of the new airport in Temon Kulon Progo, get opposition from the community. The society, forming community groups "Wahana Tri Tunggal" to do a massive rejection.The construction of the new airport necessary to increase the number of tourists to Yogyakarta in every year. The development process is targeted to be completed in 2019. The purpose of this research is to know the crisis management of government required to resolve this problem. The type of this research is qualitative research with case study method. Various shaping data deeply researchers do, as observations in Temon Kulon Progo, interviews with the Kulon Progo's Government, PT Angkasa Pura 1, Bapeda DIY, and discussions with residents. The result of this research points to the success of the strategic crisis management by the government in land acquisition for the development of Kulon Progo's new airport. Currently, the majority of them have received the government decision to relocate their settlement. The community has hope that the new airport will be able to improve their welfare with the better life. This research gives insight into management strategies of the crisis that have been done succesfully by the government regarding land acquisition to build the new airport in Kulon Progo.
\end{abstract}

Keywords: management, the new airport, and Kulon Progo.

\begin{abstract}
Abstrak
Rencana pembangunan bandara baru di Temon Kulon Progo, mendapatkan penolakan dari masyarakat sekitar. Masyarakat Kulon Progo, membentuk Kelompok Masyarakat Wahana Tri Tunggal untuk melakukan penolakan secara massive. Pembangunan bandara baru diperlukan untuk meningkatkan jumlah wisatawan ke Yogyakarta di setiap tahunnya. Proses pembangunan ditargetkan akan selesai pada tahun 2019. Tujuan dari penelitian ini adalah mengetahui strategi manajemen krisis dari pemerintah untuk menyelesaikan permasalahan penolakan rencana pembangunan bandara. Penelitian ini merupakan penelitian kualitatif dengan menggunakan metode studi kasus. Berbagai proses pengambilan data secara mendalam peneliti lakukan, seperti: melakukan observasi di Temon Kulon Progo, melakukan wawancara mendalam dengan Pemerintah Kulon Progo, PT Angkasa Pura 1, Bapeda DIY, dan diskusi dengan masyarakat sekitar. Hasil penelitian ini, menunjukkan adanya keberhasilan dari strategi manajemen krisis yang dilakukan pemerintah dalam pembebasan lahan warga guna pembangunan bandara baru di Kulon Progo. Saat ini, mayoritas masyarakat sudah menerima baik kebijakan pemerintah untuk merelokasi pemukiman mereka. Masyarakat mempunyai harapan, agar bandara baru nantinya mampu meningkatkan kesejahteraan mereka dengan adanya kehidupan yang lebih baik. Kontribusi penelitian ini adalah memberikan wawasan mengenai strategi manajemen krisis yang berhasil dilakukan oleh pemerintah dalam pembebasan lahan warga untuk membangun bandara baru Kulon Progo.
\end{abstract}

Kata kunci: manajemen krisis, bandara baru, dan Kulon Progo.

\section{Pendahuluan}

Rencana pembangunan bandara baru di Yogyakarta telah ada sejak tahun 2010 lalu, hal ini dikarenakan bandara Adisutjipto dianggap sudah tidak mampu lagi menampung banyaknya wisatawan yang berkunjung di Yogyakarta. Setiap tahunnya,
Bandara Adisutjipto yang berkapasitas 1,6 juta penumpang sudah dipakai 7,2 juta orang penumpang per tahun. Sementara bandara baru ini, ditargetkan akan menampung 14 juta penumpang, bahkan tahap kedua sampai 20 juta penumpang. Hal tersebut dilakukan, untuk meningkatkan jumlah wisatawan di 
Yogyakarta hingga 20 juta wisatawan/setiap tahunnya.

Sementara itu menurut Presiden Indonesia, kehadiran bandara ini sudah direncanakan sejak 6-7 tahun yang lalu. "Saat Gubernur DIY menemui saya, saya sampaikan segara kita mulai bersama-sama (pembangunan bandara ini). Setiap pekerjaan apapun, pasti ada resikonya. Kalau tidak diputuskan maka akan mundur dan tak akan selesai sampai kapanpun", tegas presiden.

Dari kebijakan yang telah diambil pemerintah tersebut, kemudian berbagai proses dilakukan untuk mengimplementasikan pembangunan bandara baru di Kulon Progo. Proses pertama yang dilakukan, adalah dengan memilih lokasi yang sesuai. Ada beberapa alternatif lokasi, seperti: Selomartani Sleman, Gading Airport Gunung Kidul, Gadingharjo Bantul, Bugel Kulon Progo, Temon Kulon Progo, dan Bulak Kayangan Kulon Progo. Dari proses survei yang dilakukan, akhirnya dipilihnya Temon di Kulon Progoyang menjadi lokasi bandara baru. Temon Kulon Progo, dianggap lokasi yang paling representatif dibandingkan daerah lainnya. Luas lahan yang mencukupi untuk sebuah bandara dengan konsep airport city, dan kepadatan penduduk yang tidak terlalu tinggi menjadi faktor utama pemilihan lokasi di Temon.

Didalam pembangunan bandara ini, proses paling sulit yang dilakukan adalah relokasi lahan masyarakat. Banyak diantara masyarakat yang merasa keberatan untuk direlokasi. Pro konta pun tidak dapat dihindarkan dalam hal ini. Masyarakat berdampak, kemudian membentuk Kelompok Masyarakat Wahana Tri Tunggal. Mereka melakukan penolakan keras, terhadap pembangunan bandara baru tersebut. Berbagai aksi, seperti demontrasi, pengerusakan sarana-prasarana mereka lakukan, untuk menolak pembangunan bandara ini. Alasan mereka sederhana, yakni tidak mau dipindah karena takut tidak bisa mendapatkan hidup yang lebih baik setelah kehilangan mata pencahariannya, mengingat mereka sudah terbiasa bercocok tanam di sana.

Berdasarkanhal tersebut,sudahselayaknya memang pemerintah membuat program pemberdayaan masyarakat yang nantinya menjembatani kelangsungan hidup warga berdampak ini. Dalam sebuah kesempatan Sekretaris Daerah (Sekda) Kulon Progo-Budi Wibowo, mengakui memang sampai sekarang konsep pemberdayaan masyarakat yang terkena dampak pembangunan bandara belum disiapkan. Pemerintah Kulon Progo akan menginventarisir beberapa item yang dapat dimanfaatkan untuk pemberdayaan. Misalnya saja: parkir, dan pengelolaan airport city.

Pemerintah sendiri akan terus melakukan upaya untuk mencari celah-celah pemberdayaan masyarakat sendiri. Pemerintah siap menampung aspirasi dari masyarakat. "Berbagai masukan akan dikomunikasikan dengan Angkasa Pura selaku pengelola bandara. Sehingga terjalin kerjasama pengelolaan kawasan bandara dan sekitarnya", kata Budi Wibowo-Sekda Kulon Progo.

Di tengah upaya pembebasan lahan masyarakat yang sedang berlangsung, masih banyak pula kelompok masyarakat yang bersikeras melakukan penolakan. Ada masyarakat yang telah menerima kebijakan pemerintah dengan menerima tawaran untuk direlokasi dan dibeli tanahanya, namun tak 
sedikit juga yang masih memilih bertahan di rumahnya masing-masing dan bersikeras tidak mau digusur.

Berbagai strategi komunikasi telah dilakukan pemerintah untuk memberikan pemahaman, baik dengan cara formal (sosialisasi, konsultasi publik, publisitas di media tentang pentingnya keberadaan bandara baru), ataupun dengan cara non formal (pendekaran person to person sambil minum kopi ataupun makan bersama), namun tetap saja beberapa kelompok masyarakat masih bersikeras melakukan penolakan. Bahkan beberapa kali surat peringatan telah dilayangkan, agar masyarakat segera mengosongkan rumahnya. Seolah angina lalu, hal tersebut tidak diindahkan oleh sekitar 110 masyarakat. Strategi manejemen krisis diperlukan dalam hal ini, supaya kepentingan pemerintah untuk membangun bandara baru dapat segera direalisasikan, namun juga mampu memberikan solusi atas keresahan masyarakat setempat.

Public Relations mempunyai peranan penting dalam sebuah organisasi, karena kunci keberhasilan organisasi dalam membangun citra positif di mata masyarakat sangat tergantung padanya. Terlebih apabila perusahaan sedang mengalami krisis, keberadaan Public Relations akan sangat diperlukan. Di masa krisis, seorang Public Relations harus mampu mengidentifikasi setiap permasalahan yang muncul serta nantinya mengambil langkah-langkah yang tepat, guna menyelesaikan krisis tersebut. Krisis sendiri merupakan sebuah keadaan gawat darurat atau sangat genting, di mana situasi tersebut dapat merupakan titik balik atau sebaliknya. (Soemirat, 2005: 181).
Melihat definis krisis di atas, yakni merupakan sebuah keadaan gawat darurat dan mungkin saja akan menimbulkan keterkejutan dari pihak yang mengalaminya, akan tetapi pada dasarnya krisis tidak terjadi begitu saja, melainkan akan memberikan sintalsinyal terjadinya krisis terlebih dahulu. Hal ini sebagainya yang dikatakan Newsome (2000: 480), bahwa krisis sebenarnya dapat dideskripsikan, dikategorikan, bahkan biasanya krisis bisa diprediksikan terlebih dahulu. Oleh karenanya, setiap organisasi diharapkan mampu melakukan strategi antisipasi terjadinya krisis ini dengan baik, dengan mengenali tanda-tanda terjadinya krisis.

Pada umumnya, krisis diartikan sebagai sebuah peristiwa yang akan memberikan implikasi negatif pada organisasi daripada sebaliknya. Hal ini senada dengan apa yang disampaikan oleh Kathleen Fear-Banks (2007: 65), sebagai berikut:

"A major occurance with a potentially negative outcome affecting organization, company industry, as well as it publics, products, services, or god name"

Krisis bisa terjadi kapan dan dimana saja, melalui berbagai macam peristiwa. Berbagai jenis krisis yang dapat muncul antara lain : kecelakaan kerja, masalah lingkungan, masalah perburuhan, masalah produk, masalah dengan investor, desas-desus isu, peraturan pemerintah, masalah konsumen, maupun terorisme. Di dalam krisis tersebut, tentu akan menimbulkan berbagai hal yang sangat merugikan bagi keberlangsungan organisasi dan juga menimbulkan keresahan bagi masyarakat serta citra perusahaan menjadi taruhan dalam hal ini (Soemirat, 2005: 182). 
Di dalam melakukan penanganan terhadap krisis perlu dilakukan tindakan yang cepat dan tepat. Adanya dukungan dari semua pemangku kepentingan organisasi juga sangat diperlukan dalam hal ini. Dengan demikian, diharapkan semua pihak akan mampu bekerjasama guna mencari solusi terbaik dalam menyelesaikan krisis tersebut.

Ketika suatu organisasi atau perusahaan sedang mengalami krisis, tentunya diperlukan adalah upaya penanganan yang tepat untuk menyelesaikan krisis tersebut. Penanganan krisis tersebut dapat dikatakan sebagai sebuah manajemen krisis. Di mana, manajemen krisis sendiri merupakan sebuah proses yang digunakan oleh sebuah organisasi berkaitan dengan isu-isu yang ada di luar kendali (Smith, 2005: 15).

Sementara itu Regester, and Judy (2003: 131), mendefinisikan manajemen krisis sebagai:

"An event which causes the company to become the subject of widespread, potentially unfavourable, attention from the international and national media and orther groups such as customers, shareholders, employess and their families, politicians, trade unionist and environmental pressure groups who, for one reason or another, have a vested interest in the activities of the organization".

Melalui pernyataan diatas, dapat diambil sebuah benang merah, bahwa sebuah krisis harus menjadi perhatian seluruh pemangku kepentingan organisasi. Mengingat krisis berpotensi untuk menarik perhatian media baik nasional maupun lokal yang biasanya bersifat kurang menyenangkan. Oleh karenanya, dalam sebuah penanganan krisis diperlukan adanya langkah-langkah yang tepat untuk menanggulanginya, berikut ini adalah langkahlangkah tersebut, (1) Identifikasi Krisis, yaitu proses identifikasi memerlukan adanya suatu riset. Bila krisis terjadi dengan cepat penelitiannya harus dilakukan secara informal dan kilat. Dalam hal ini, adalah pengumpulan data serta penarikan kesimpulan harus dilakukan dalam hari yang sama. Hal itulah yang menjadi alasan mengapa seorang praktisi public relations harus mempunyai kecakapan dan kepekaan untuk mengumpulkan data; (2) Analisis Krisis, yaitu seorang praktisi Public Relations tentunya dituntut untuk melakukan analisis. Analisis harus dilakukan dengan penuh kecermatan untuk dapat menangkap indikasi-indikasi yang muncul dari setiap permasalahan. Analisis juga mempunyai cakupan yang sangat luas, mulai dari analisis parsial sampai analisis integral yang saling terkait perlu dilakukan dalam hal ini; (3) Isolasi Krisis, yaitu, krisis merupakan suatu penyakit yang harus secepatnya ditanggulangi agar dampaknya tidak menyebar kemana-mana. Hal itulah yang menjadi alasan mengapa perlu dilakukan pencegahan krisis agar tidak menyebar luas dengan cara isolasi ataupun karantina sebelum tindakan serius dilakukan; (4) Memilih Strategi, yaitu Strategi yang tepat diperlukan untuk menangani sebuah krisis. Ada beberapa strategi yang dapat digunakan untuk menangani krisis, sebagai berikut Defensive Strategi (Strategi Defensif), beberapa langkah-langkah yang; (5) Dapat diambil meliputi hal-hal seperti mengulur waktu, tidak melakukan apa-apa (not in action atau low profile), membentengi diri dengan kuat (stone walling), adaptive strategi (Strategi Adaptif), dynamic Strategy (Strategi Dinamis); (6) Program Pengendalian, yaitu langkah-langkah untuk melakukan strategi generik yang telah dirumuskan. Berbagai 
strategi generik ini dapat dirumuskan jauhjauh hari sebelum krisis muncul, di mana nantinya berfungsi sebagai guidance yang dapat dimanfaatkan oleh para eksekutif untuk mengambil langkah pasti (Kasali, 2000: 231 -233).

Kesuksesan organisasi tidak hanya ditentukan oleh faktor internal, melainkan juga external. Salah satu elemen penting untuk menunjang kesuksesan organisasi, adalah masyarakat. Kehadiran organisasi di tengahtengah lingkungan sosial, tentu membutuhkan support dari organisasi tersebut. Menjalin kedekatan dengan masyarakat, merupakan sebuah hal yang perlu dilakukan organisasi.

Dewasa ini strategi untuk menjalin kedekatan dengan masyarakat dikenal dengan istilah Community Relations. Menurut Iriantara (2004: 20), community relations merupakan peningkatan partisipasi dan posisi organisasi di dalam sebuah komunitas melalui berbagai upaya untuk kemaslahatan bersama bagi organisasi dan komunitas.

Di dalam melaksanakan program community relations tersebut organisasi harus mengambil langkah-langkah serta strategi yang tepat dalam kegiatan community relations. Berikut beberapa langkah, tersebut (1) Merumuskan komunitas organisasi dan berbagai kelompok yang ada di dalamnya; (2) Menyusun pesan yang hendak disampaikan; (3) Memilih metode yang paling baik dalam penyampaian pesan; (4) Melaksanakan program community relations organisasi; (5) Menentukan tujuan program community relations organisasi; (6) Melakukan analisis hasil.

Selain hal di atas, mengetahui karakteristik dari masing-masing khalayak juga menjadi hal yang perlu diperhatikan oleh organisasi. Sehingga organisasi dapat menyesuaikan apa yang menjadi keinginan masyarakat terhadap organisasi. Hal lain yang perlu dipahami organisasi dalam program community relations, bahwa dalam program community relations diperlukan adalah adanya titik temu untuk dijadikan dasar untuk membangun kegiatan guna mendatangkan kemanfaatan bagi organisasi itu sendiri dan tentunya komunitas (Iriantara, 2007: 40).

Berdasarkan latar belakang yang sudah dipaparkan, tujuan dari penelitian ini adalah Tujuan dari penelitian ini adalah mengetahui strategi manajemen krisis dari pemerintah untuk menyelesaikan permasalahan penolakan rencana pembangunan bandara.

\section{Metode Penelitian}

Penelitian ini dilakukan dengan metode studi kasus. Menurut Newman (2006: 47), studi kasus merupakan penelitian yang berupaya untuk melakukan penyelidikan mendalam dari berbagai macam informasi mengenai berbagai macam unit (kasus) untuk 1 periode atau beberapa metode majemuk. Di dalam melakukan penelitian studi kasus ini, peneliti melakukan wawancara mendalam kepada pihak-pihak terkait, seperti: Pemerintah Kabupaten Kulon Progo, PT Angkasa Pura 1 Yogyakarta, maupun masyarakat setempat.

Dari data yang peneliti kumpulkan, kemudian peneliti melakukan proses reduksi data. Reduksi data, dilakukan dengan memilahmilah, antara data yang berkaitan langsung dengan penelitian ini (utama), dan data yang tidak berkaitan langsung (pendamping). Setelah itu, peneliti melakukan analisis secara mendalam terhadap data utama yang berhasil ditemukan. Dari proses analisis, selanjutnya 
peneliti dapat melakukan kesimpulan terkait upaya-upaya manajemen krisis yang dilakukan pemerintah dalam proses pembangunan bandara baru di Kulon Progo ini.

\section{Hasil Penelitian dan Pembahasan \\ Dinamika Komunikasi Pembangunan Bandara baru Kulon Progo}

Proses pembangunan bandara baru di Kulon Progo ini memang tidak mudah dilakukan dan memerlukan perhatikan extra, terutama dalam proses pengadaan lahan sekarang ini. Sebagaimana telah dipaparkan di awal, pro kontra mewarnai proses pengadaaan lahan ini. Kelompok Masyarakat Wahana Tri Tunggal (WTT) merupakan masyarakat yang kontra dengan rencana pembangunan bandara baru ini. Berbagai aksi dilakukan oleh WTT untuk menggagalkan rencana pembanguunan bandara baru, akan tetapi seiring dengan proses komunikasi yang dilakukan pemerintah WTT sekarang ini telah dapat menerima kebijakan pemerintah untuk merelokasi pemukiman mereka guna pembangunan bandara baru.

Berakhirnya WTT tidak menyebabkan konflik antara pemerintah dengan masyarakat berakhir. Munculah kelompok masyarakat lain yang menamakan diri sebagai Aliansi Penolak Pembangunan Bandara Baru. Sampai dengan saat ini mereka bersikeras tidak mau meninggalkan rumah mereka, guna direlokasi. Jumlah mereka tidak sedikit, yakni sekitar 116 masyarakat. Mereka beralasan bahwa bandara baru tidak pro rakyat kecil. Selain itu mereka juga memiliki kekhawatiran, kalau tidak bisa memperoleh pekerjaan lain apabila mereka berpindah tempat tinggal.

Itulah yang menjadi tugas pemerintah Kulon Progo saat ini, yakni menyakinkan masyarakat yang tergabung dalam Aliansi Penolakan Bandara Baru tersebut untuk direlokasi. Selama ini pemerintah sendiri, tidak bertinggal diam. Berbagai proses pendekatan untuk menjalin komunikasi telah dilakukan oleh pemerintah baik dari Pemerintah Kabupaten Kulon Progo sendiri, Pemerintah DIY, maupun PT Angkasa Pura 1. Beberapa kali, pemerintah telah melayangkan surat peringatan kepada mereka, untuk segera mengosongkan rumah. Mereka dengan tegas menolak, dan tetap menempati rumah sampai dengan saat ini.

Jika di gambarkan, berikut adalah bagan mengenai dinamika komunikasi yang terjadi antara pemerintah, dengan masyarakat terkait dengan rencana pembangunan bandara (Gambar 1).

Berdasarkan Gambar 1, nampak bahwa telah ada upaya-upaya yang dilakukan pemerintah untuk melakukan pendekatan komunikasi kepada masyarakat sekitar. Misalnya saja telah adanya proses pemanfaatan media komunikasi, dan pembentukan media center. Media-media komunikasi yang dipakai pemerintah, seperti: media sosial, website, maupun blog. Hal tersebut, dimaksudkan pemerintah untuk mengefektifkan proses komunikasi yang dilakukan. Melalui pemanfaatan media, diharapkan proses komunikasi bisa cepat dilakukan, terutama dalam pemberikan pemahaman bagi masyarakat sekitar tentang perlunya pembangunan bandara baru ini. Bagi masyarakat luas, adanya media komunikasi dimaksudkan untuk mensosialisaskan progress pembangunan bandara ini. Dengan demikian nantinya akan ada dukungan dan peran aktif dari masyarakat luas. 


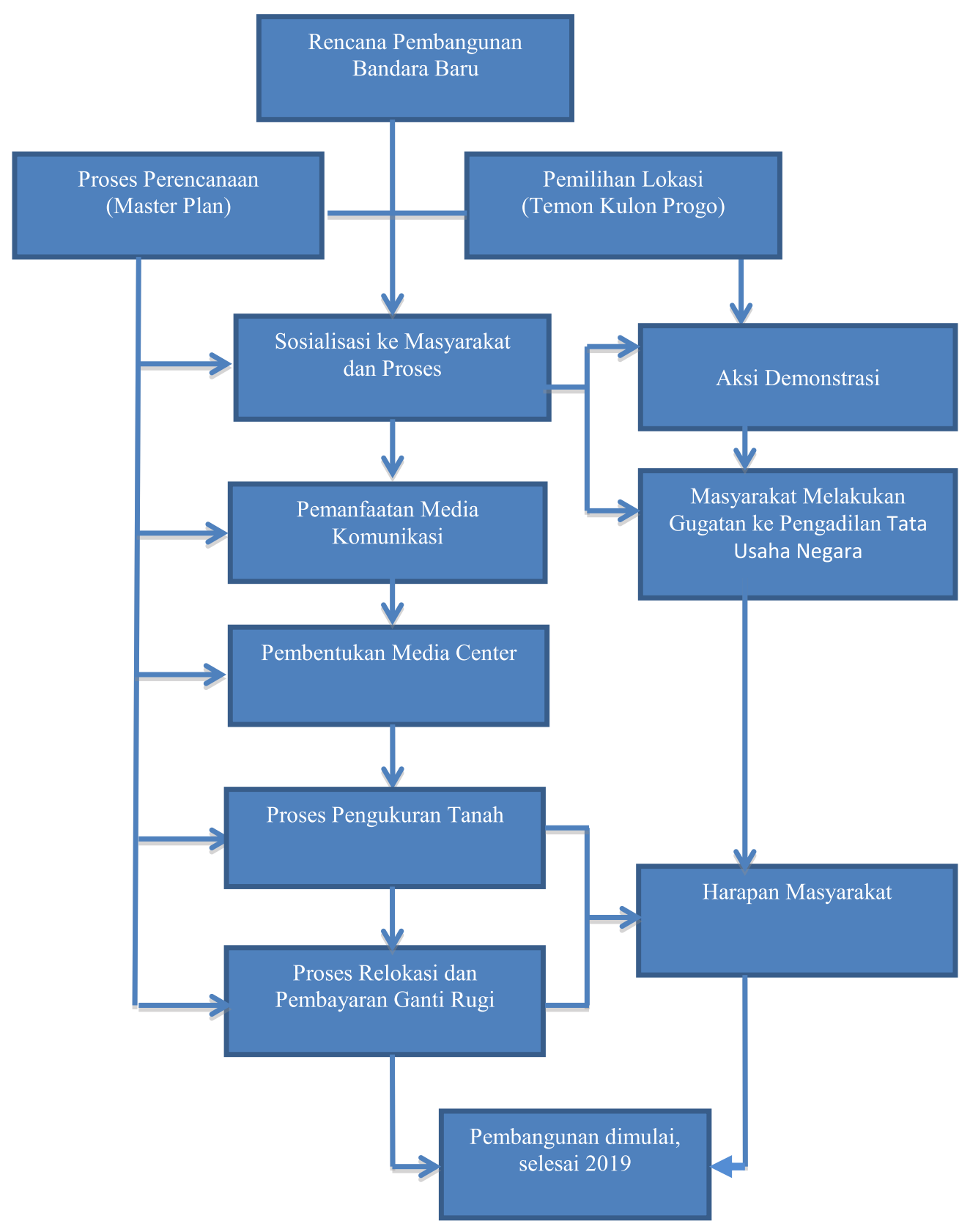

Gambar 1.

Dinamika Komunikasi Pembangunan Bandara Baru

(Sumber : Data Peneliti 2017)

\section{Manajemen Krisis Pemerintah Kulon Progo dalam Pembangunan Bandara Baru}

Sebagaimana diketahui, bahwa rencana pembangunan bandara baru ini pada awalnya mendapatkan berbagai penolakan dari masyarakat. Masyarakat yang bergabung dalam Kelompok Wahana Tri Tunggal, melakukan berbagai aksi untuk menggagalkan rencana pembangunan bandara ini. Mereka beberapa kali melakukan aksi demontrasi untuk membatalkan rencana pembangunan tersebut. Tidak hanya demonstrasi damai saja, akan tetapi mereka sempat melakukan aksi dengan membakar ban, melempar batu, dan lain sebagainya. Saat itu, mereka menuntut agar bisa dipertemukan dengan 
Gubernur, untuk menyampaikan aspirasi mereka. Berikut ini, adalah foto-foto aksi demonstrasi yang dilakukan oleh Kelompok Wahana Tri Tunggal dalam aksi menuntut pembatalan rencana pembangunan bandara baru di Kulon Progo.

Ibarat sebagai sebuah krisis, diperlukan segera strategi manajemen krisis yang tepat. Manajemen krisis sendiri merupakan sebuah proses yang digunakan oleh sebuah organisasi berkaitan dengan isu-isu yang ada di luar kendali (Smith, 2005: 15). Hal tersebutlah, yang dipahami oleh pemerintah. Menghadapi permasalahan tersebut, pemerintah tidak tinggal diam. Pemerintah responsif menanggapi aksi-aksi yang dilakukan oleh masyarakat. Mengingat jika tidak ditanggapi, situasi tersebut tentu akan mengganggu stabiltas wilayah Kulon Progo sendiri.

Berbagai upaya dilakukan pemerintah untuk mempercepat proses pembangunan bandara di Kulon Progo ini. Komunikasi dengan berbagai pihak dilakukan, untuk mensinergiskan berbagai kepentingan pihak-pihak yang terkait, baik dari internal pemerintah sendiri, maupun dengan masyarakat berdampak.
Pemerintah melakukan berbagai koordinasi dalam ranah internal untuk membuat langkah strategis, guna menyelesaikan permasalahan ini. Sebelum melakukan sosialisasi kepada masyarakat, pemerintah selalu berkoordinasi satu sama lain. Koordinasi tersebut dihadiri oleh Pemerintah DIY, Pemerintah Kabupaten Kulon Progo, PT Angkasa Pura 1, dan Anggota Dewan DPRD DIY.

Setelah koordinasi dilakukan, maka selanjutnyapemerintahmelakukan sosialisasi kepada masyarakat, dalam proses konsultasi publik. Dalam proses konsultasi publik, pemerintah menawarkan beberapa alternatif kepada masyarakat. Selanjutnya apabila masyarakat setuju, maka dilanjutkan dengan proses pengukuran tanah, yang kemudian dilanjutkan dengan proses pembayaran tanah. Dalam proses pembayaran, masyarakat juga diberikan arahan dari konsultan keuangan untuk mendampingi proses pembayaran. Sementara pada proses ganti rugi, pemerintah tidak hanya membeli tanah dan bangunan milik masyarakat saja, akan tetapi sesuai dengan kesepakatan pemerintah juga membeli benda-benda yang ada di atas tanah

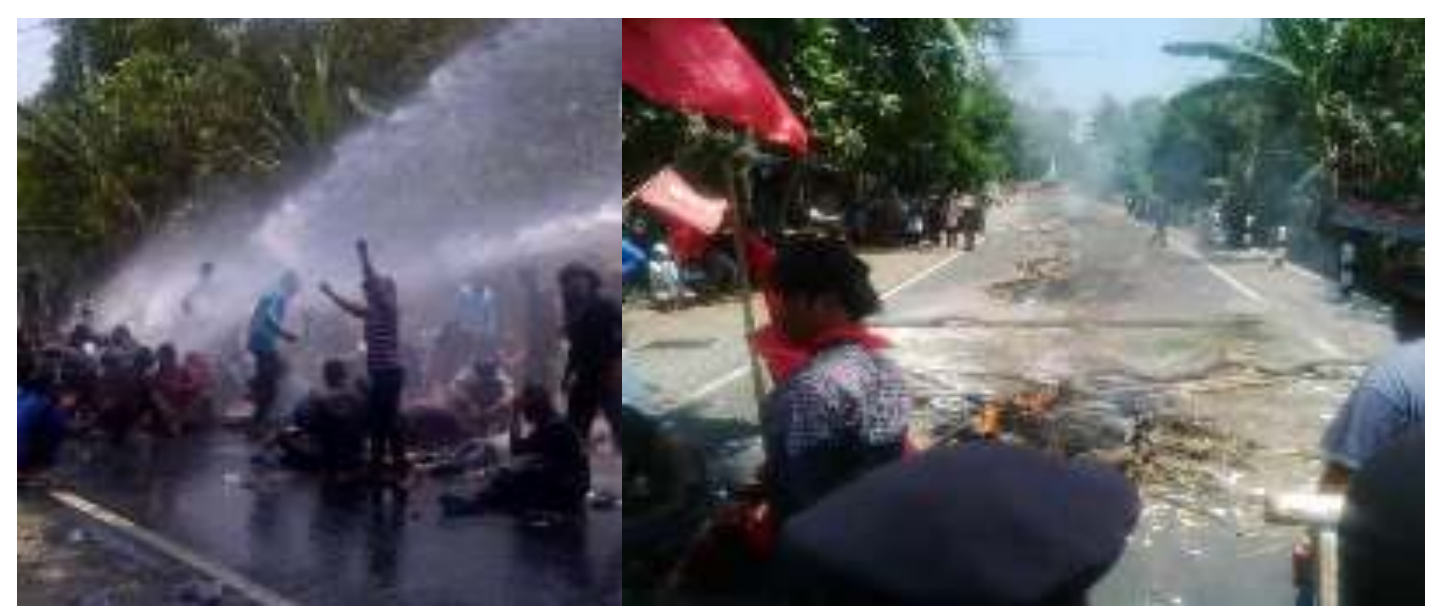

Gambar 2.

Demonstrasi Kelompok Masyarakat Wahana Tri Tunggal Sumber: Dokumemtasi PT Angkasa Pura 1 


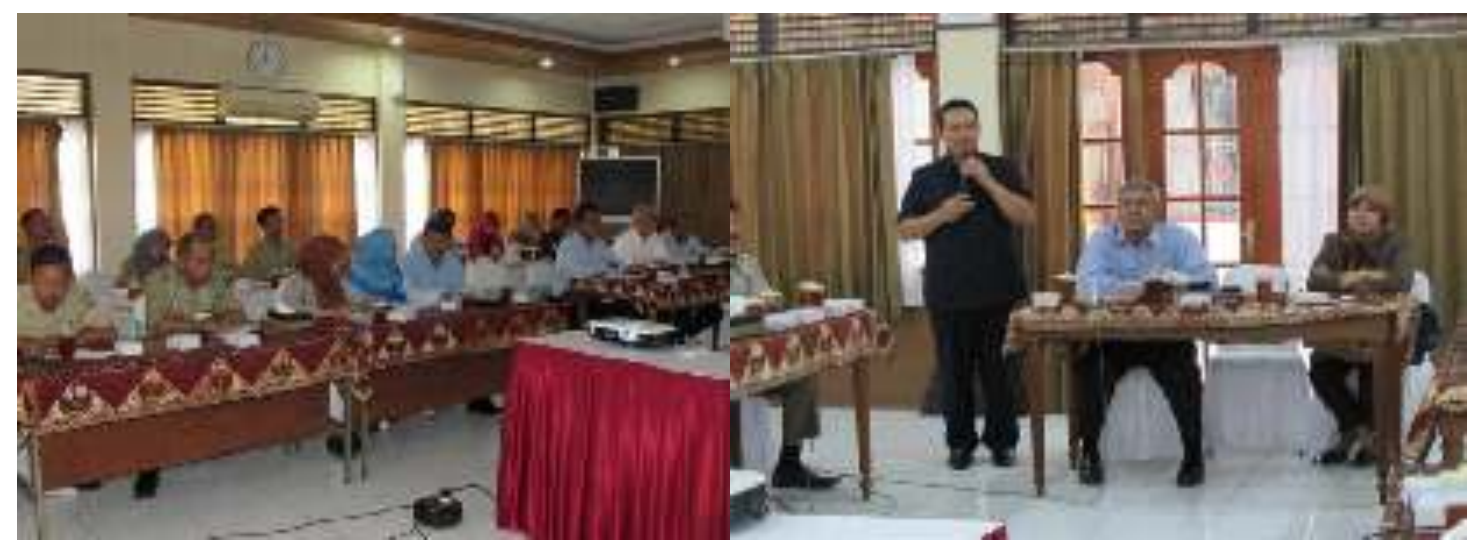

Gambar 3.

Koordinasi Internal Pemerintah Sebelum Melakukan Sosialisasi Kepada Masyarakat Sumber: Dokumentasi PT Angkasa Pura 1

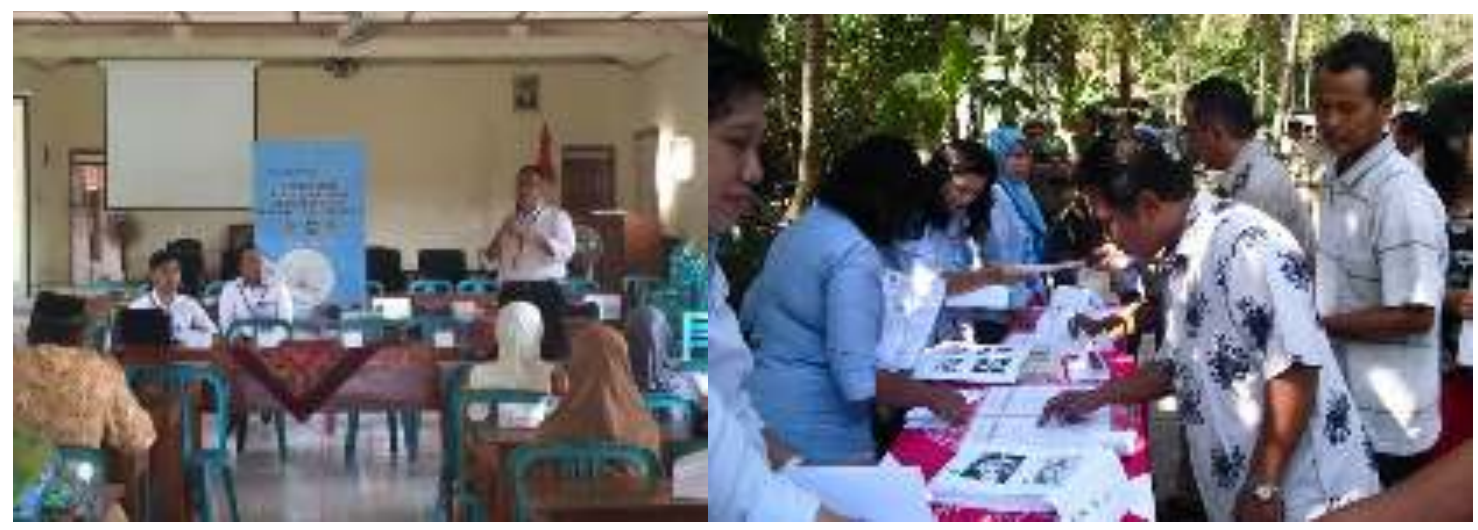

Gambar 4.

Proses Konsultasi Publik dan Pendampingan dari Konsultan Keuangan Sumber: Dokumentasi PT Angkasa Pura 1

tersebut, misalnya: pepohonan, dan barang lain yang ditinggalkan.

Upaya manjemen krisis lainnya, yang dilakukan pemerintah adalah dengan mengadakan beberapa pelatihan untuk peningkatan kapasitas masyarakat. Pelatihan tersebut ditujukan untuk meningkatkan kesejahteraan mereka pasca berpindah tempat tinggal. Jika masyarakat banyak yang tidak mau direlokasi karena adanya ketakutan untuk tidak mendapatkan pekerjaan yang lebih baik dari sebelumnya, maka berbagai pelatihan ini diadakan untuk menjawab keraguan tersebut. Berbagai pelatihan diberikan oleh pemerintah, misalnya pelatihan menjadi petugas keamanan, petugas pelayanan bandara, maupun pelatihan kewirausahaan lainnya.

Berdasarkan hal tersebut, masyarakat berdampak tidak perlu ragu untuk menerima tawaran pemerintah guna direlokasi rumahnya. Pemerintah berusaha untuk mengakomodir berbagai kepentingan masyarakat, salah satunya dengan program-program pelatihan yang diberikan ini. Pengetahuan akan banyaknya manfaat yang didapatkan pasca adanya pembangunan bandara baru ini, nampaknya yang perlu ditingkatkan pemerintah. Masyarakat dengan karakteristik pedesaan, tentu kurang cepat dalam menerima perubahan. Oleh karenanya, upaya-upaya 
pendekatan personal kepada masyarakat, dengan memberikan edukasi bagi peningkatan kesejahteraan mereka sangatlah diperlukan.

\section{Pemanfaatan Media Komunikasi}

Pada bulan Januari 2017 lalu, Pemerintah Kulon Progo telah resmi membentuk media center untuk memfasiltasi proses komunikasi dan informasi masyarakat terkait bandara baru di Kulon Progo. Semua informasi yang dibutuhkan masyarakat dapat difasilitasi di sana. Media Center ini di bawah kendali dari Dinas Komunikasi dan Informasi Kulon Progo. Jika dahulu aktivitas komunikasi difasilitasi oleh Humas Pemerintah Kabupaten Kulon Progo, maka sekarang ini dengan adanya Media Center diharapkan aktivitas komunikasi dapat diambil alih.

Di dalam media center diberikan berbagai inromasi terkait dengan proses pembangunan bandara baru di Kulon Progo. Media Center ini banyak dimanfaatkan oleh para rekan media yang ingin mengetahui progres pembangunan bandara baru. Sementara masyarakat Kulon Progo sendiri berkunjung ke sana, untuk menyampaikan keluhan/aspirasi/pertanyaan terkait dengan proses ganti rugi maupun relokasi. Sementara masyarakat umum memanfaatkan media center ini, sebagai pusat informasi untuk

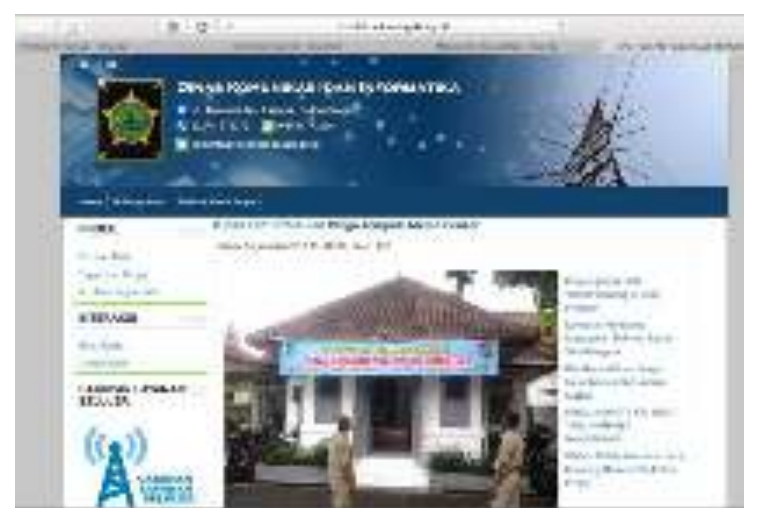

Gambar 5.

Media Center Dinas Kominfo Kulon Progo Sumber : www.kominfo.kulonprogokab.go.id kebutuhan khusus, misalnya study maupun penelitian.

Berbagai arsip dan dokumentasi kegiatan pembangunan bandara baru ada di media center ini. Mulai dari proses perundingan, survei lokasi, aksi demonstrasi masyarakat, proses relokasi, dang anti rugi, serta proses peresmian pembangunan pertama bandara baru yang langsung dilakukan oleh Presiden Jokowi.

Berbagai media komunikasi yang dikelola pemerintah tersebut, menunjukkan bahwa telah ada komunikasi dua arah antara pemerintah dengan masyarakat. Penggunaan media komunikasi dalam upaya manajemen krisis terhadap penolakan masyarakat, efektif untuk mengurangi krisis kepercayaan masyarakat. Hal ini dapat dilihat dari sudah tidak adanya pergerakan masyarakat untuk menolak pembangunan bandara ini. Hampir semua masyarakat berdampak, sudah bisa menerima keputusan dari pemerintah untuk membangun bandara baru ini. Saat ini mereka sudah menempati rumah-rumah baru sebagai upaya relokasi. Mereka berharap bahwa proses pembayaran ganti rugi segera diselesaikan, dan bisa mendapatkan pekerjaan yang lebih layak.

Pengelolaan media komunikasi yang tepat mampu mengurangi dampak krisis yang lebih luas. Media komunikasi sebagai sarana komunikasi antara pemerintah dengan masyarakat luas. Dengan adanya media komunikasi yang dibangun, diharapkan mampu berkontribusi pada pengelolaan krisis, terutama dalam kaitannya dengan penolakan dari masyarakat. Hal ini sebagaimana pendapat Li Guevera, Herdon, Caragea, Kishore, Squicciarini \& Tapia 
dalam Hayley Watson (2016: 17), bahwa beberapa tahun terakhir ini melihat adanya kemajuan yang besar dalam bagaimana data di media sosial mampu berkontribusi pada pengelolaan krisis. Data dari media social tersebut, mampu berkontribusi pada proses analisis krisis.

Tidak hanya komunikasi secara langsung, namun juga melalui media-media komunikasi yang ada. Media komunikasi yang dibangun tidak hanya ditujukan kepada masyarakat di Kulon Progo saja, namun juga sebagai publikasi kepada masyarakat luas. Harapan pemerintah dengan adanya publikasi di berbagai media komunikasi, akan adanya dukungan dari masyarakat luas terhadap rencana pembangunan bandara di Kulon Progo ini.

Sebagaimana telah peneliti paparkan di atas, bahwa rencana pembangunan bandara baru ini telah ada sejak tahun 2010 lalu. Melalui proses panjang dan tarik ulur dari pemerintah sendiri sampai kemudian turunlah IPL, yang kemudian diwarnai dengan pro kontra dari masyarakat tentu bukan persoalan yang mudah untuk diselesaikan. Hal tersebut tentu saja menjadi penghambat proses pembangunan bandara ini. Upaya manajemen krisis dilakukan untuk menanggulangi penolakan dari masyarakat berdampak. Manajemen krisis sendiri merupakan sebuah proses yang digunakan oleh sebuah organisasi berkaitan dengan isu-isu yang ada di luar kendali (Smith, 2005: 15).

Strategi Manejemen Krisis merupakan hal penting yang dilakukan untuk mencarikan solusi bersama atas permasalahan ini. Dalam upaya melakukan strategi manajemen krisis, upaya untuk saling berkomunikasi antara kedua pihak sangatlah diperlukan. Ketika masing-masing pihak mempunyai kepentingan sendiri-sendiri, maka dengan adanya komunikasi dan interaksi diantaranya keduanya maka akan tercapainya kesamaan persepsi.

Interaksi antara pemerintah dan masyarakat memang sudah cukup intens diantara keduanya, sehingga telah adanya persamaan persepsi. Masyarakat telah menyadari bahwa sesungguhnya, pembangunan bandara ini adalah kepentingan bersama yang memberikan manfaat jauh lebih besar dari sekedar kepentingan kelompok masyarakatnya. Begitu pun hal pemerintah, yang telah berupaya untuk tidak mengesampingkan kepentingan masyarakat berdampak, yang kemudian mencoba memberikan beberapa alternatif atas dampak rencana pembangunan bandara ini. Adanya opsi untuk ganti rugi, relokasi, atau campuran diantara keduanya tentu menjadi sebuah upaya yang patut dihargai.

Pemerintah tentu bisa saja menggunakan cara-cara untuk mengintimidasi masyarakat agar mereka mau menjalankan apa yang dikehendaki oleh pemerintah, akan tetapi tentu hal tersebut tidak lazim dilakukan terlebih di dalam negara demokrasi seperti Indonesia ini. Pro kontra menjadi sebuah hal wajar dalam polemik pengambilan kebijakan. Jika tidak diselesaikan dengan baik, tentu hal tersebut akan menyebabkan terjadinya konflik yang berkepanjangan.

Adanya rasa kekecewaan, ketidak percayaan, kecurigaan merupakan sebuah 
potensi yang dapat menimbulkan konflik. Hal tersebut sebagaimana dikatakan oleh Suranto (2010: 122), tentang potensi-potensi yang mungkin dapat menyebabkan terjadinya konrflik, sebagai berikut: (1) Sesuatu yang berharga di masyarakat, pada dasarnya tidak dapat dibagi rata. Misalnya posisi ketua kelompok masyarakat, yang hanya dijabat oleh satu orang saja, sementara yang menginginkan banyak; (2) Setiap individu memiliki kepentingan dan saling bersaing untuk memenuhi kepentingan tersebut. Setiap warga mempunyai pendapat, dan berusaha mempertahankannya; (3) Kedudukan orang-orang yang terkait dengan kegiatan kelompok atau organisasi tidak sama. Perbedaan kedudukan tersebut, menyebabkan rawan terjadinya konflik; (4) Setiap orang memiliki sikap yang berbeda-beda. Biasanya, mereka merasa bahwa sikapnya lebih benar dibandingkan lainnya, hal tersebut juga menyebabkan terjadinya konflik; (5) Kekecewaan masyarakat yang berlarut-larut, karena harapan tidak sesuai dengan kenyataan. Adanya kekecewaan yang berlarut-larut dapat memicu terjadinya konflik.

Adanya kekhawatiran dari masyarakat sebagaimana disebutkan dalam potensipotensi konflik tersebut, merupakan penyebab mengapa beberapa kelompok masyarakat masih bersikukuh untuk mempertahan rumahnya. Masyarakat Temon yang sudah sejak lama menjadi petani, tentu berpikir panjang jika harus merubah mata pencahariannya sebagai petani. Selain itu, masyarakat yang sudah setuju untuk dibeli tanahnya pun sekarang ini banyak yang kembali melakukan protes. Hal tersebut, dikarenakan proses pembayaran ganti rugi yang belum juga selesai dilakukan, prosedur yang sulit menyebabkan mereka harus bolak-bolik ke Pemda, dan lain sebagainya. Etikat baik dari pemerintah untuk segera menyelesaikan permasalahan ini tentu sangat diharapkan dari masyarakat. Jika tidak, tentu masyarakat yang sudah pro pun dapat berbalik menjadi kontra dan mengakibatkan masalah ini semakin berlarut-larut.

Proses pengadaan relokasi juga perlu segera diselesaikan, masyarakat yang sudah terlanjur meninggalkan rumahnya, tentu menginginkan untuk segera mendapatkan tempat tinggal yang baru. Proses komunikasi dilakukan pemerintah dengan banyak cara dalam rencana pembangunan bandara ini. Baik komunikasi di internal pemerintah sendiri, berkoordinasi dengan elemen pemerintah lain yang berkaitan langsung dengan proses pembangunan bandara ini. Komunikasi di ranah internal bertujuan untuk mengkoordinasikan tentang tugas dan tanggung jawab dari masing-masing instansi untuk mega proyek pembangunan bandara ini. Berdasarkan data yang peneliti dapatkan, beberapa diantara masyarakat masih merasa bahwa masalah birokrasi di pemerintah ini menjadi sebuah penghambat mereka untuk mendapatkan hak-hak mereka. Oleh karenanya, di sini pemerintah seharusnya mampu berkoordinasi dengan baik, sehingga dalam memberikan pelayanan terkait berbagai aspirasi dari masyarakat dapat dilakukan secara maksimal.

Komunikasi dilakukan pemerintah dengan berbagai elemen masyarakat. Pemerintah pun telah melakukan berbagai jenis 
komunikasi external kepada masyarakat baik secara formal dan non formal. Misalnya: melalui konsultasi publik, nongkrong bersama, bahkan mendatangi satu per satu rumah. Hal tersebut dilakukan untuk memberikan pemahaman kepada masyarakat akan pentingnya bandara baru bagi masyarakat, sehingga masyarakat berkenan untuk direlokasi.

Jika sekarang ini ada beberapa di antara masyarakat yang masih menolak terhadap rencana pembangunan bandara, maka sesungguhnya mereka hanya perlu waktu saja untuk beradaptasi dengan perubahan sosial yang ada. Tentu bukan persoalan yang mudah untuk berpindah ke dalam kondisi yang baru. Hal penting yang harus dilakukan pemerintah adanya terus berupaya untuk menyakinkan masyarakat, bahwa justru rencana pembangunan bandara ini adanya sebuah proses untuk menuju lebih baik. Adanya sarana tranportasi yang memadai, adanya tenaga kerja yang terserap, adanya peningkatan perekonomian, dan sebagainya. Sehingga dari sana tentu masyarakat akan sadar, bahwa pembangunan bandara ini diperlukan.

Proses pembangunan bandara saat ini memang tengah dilaksanakan dan diperkirakan akan selesai pada tahun 2019 mendatang. Banyak harapan yang diberikan masyarakat akan pembangunan ini. Masyarakat menginginkan adanya kenaikan derajat kesejahteraan dibandingkan sebelumnya. Dalam ilmu komunikasi kita mengenal adanya program community relations, dimana merupakan peningkatan partisipasi dan posisi organisasi di dalam sebuah komunitas melalui berbagai upaya untuk kemaslahatan bersama bagi organisasi dan komunitas. (Iriantara, 2004: 20).

Mengoptimalkan keberadaan organisasi di tengah-tengah lingkungan masyarakat menjadi sebuah kepentingan yang perlu dilakukan. Peran aktif organisasi untuk membantu meningkatkan kesejahteraan masyarakat diperlukan sebagai upaya timbal balik, terkait izin sosial yang telah diberikan masyarakat terkait keberadaan organisasi. Jika nantinya pembangunan bandara baru telah selesai, dan bahkan mulai beroperasi tugas selanjutya yang perlu diperlukan pemerintah adalah upayaupaya pengembangan masyarakatsekitaruntuk menumbuhkan jiwa-jiwa kewirausahaan. Adanya bandara, tentu saja membuat perekonomian masyarakat sekitar akan meningkat, dengan adanya peluang-peluang usaha kecil menengah. Tugas pemerintah adanya pendorong lahirnya ekonomi kreatif di masyarakat sekitar. Kemudian, akan adanya kemandirian, dan peningkatan kesejahteraan mereka atas adanya bandara baru dengan konsep airport city ini.

Inilah yang kemudian perlu diketahui bersama, dan dipahami oleh masyrakat yang sampai saat ini masih melakukan penolakan. Di awal proses pembebasan lahan bandara, ada banyak kekhawatiran dari masyarakat terkait bagaimana hidup mereka ke depan. Mengingat sudah sejak lama mereka mengantungkan hidupnya dari bertani. Jika memang saat ini mereka sudah mempunyai cukup uang atas proses ganti rugi yang dilakukan, akan tetapi persoalan berikutnya adalah bagaimana mereka harus memutar uang tersebut untuk hidup selanjutnya. 
Atas hal ini pemerintah juga telah menyadarinya, sehingga pemerintah juga telah membuat berbagai pembekalan dan pelatihan untuk masyarakat, seperti: kewirausahaan, dan peningkatan keterampilan jenis lainnya. Pelatihan tersebut tentu harus dilakukan secara berkesinambungan, agar supaya bukan hanya masyarakat mempunyai keterampilan untuk berwirausaha dan mempunyai ilmu untuk membuat sebuah produk/jasanya saja, melainkan mereka juga hendaknya dibekali dengan usaha-usaha pengembangannya, seperti halnya masalah pemasaran dari produk/jasa yang telah dihasilkan tersebut.

Sebuah institusi seperti halnya pemerintah diharapkan mampu memiliki kesadaran yang tinggi untuk mengetahui apa yang sesungguhnya menjadi dambaan dari komunitas bagi kesejahterananya. Menurut Cutlip dan Center dalam Effendy (1999: 201), hubungan yang baik dengan komunitas dapat terjalin apabila adanya kesadaran dari organisasi untuk memenuhi kebutuhan dari komunitas tersebut. Hal-hal yang menjadi kepentingan dari masyarakat, hendaknya dapat diperhatikan oleh organisasi. Kegiatankegiatan pengembangan masyarakat idealnya dilakukan dengan selalu berlandaskan pada kepentingan masyarakatnya. Strategi organisasi untuk membantu komunitas, tentu akan menumbuhkan persepsi baik komunitas terhadap organisasi.

Saat ini masyarakat sudah tidak lagi mempermasalahan adanya relokasi pemukiman, akan tetapi mereka menunggu janji pemerintah untuk bisa memberikan pekerjaan yang lebih baik dari sebelumnya. Oleh karenanya, ke depan upaya pemerintah harus mengarah ke sana. Yakni untuk meningkatkan kesejahteraan masyarakat. Hal ini sebagai upaya recovery, seperti dalam teori manajemen krisis. Yakni orang yang sedang dalam proses penyembuhan dan kemudian tidak dapat menahan diri, dan penyembuhannya tidak tuntas benar, maka akan kembali lagi ke tahap prodromal (munculnya krisis) kembali. (Kasali, 2000: $273-230)$.

Langkah pertama yang bisa dilakukan pemerintah dalam hal ini adalah melakukan pemetaan terkait potensi-potensi pengembangan masyarakat di sekitar bandara. Sehingga nantinya akan menjadi konsep airport city yang di dalamnya juga ada kemandirian masyarakat dalam mengembangan potensipotensi yang ada. Sehingga masyarakat lokal tidak hanya dilatih untuk menjadi sumber daya manusia di internal bandara saja, namun juga mampu menjadi pengusaha-pegusaha lokal mandiri dengan adanya bandara ini, karena tentu jumlah wisatawan yang berkunjung juga akan semakin meningkat. Oleh karenanya, pengembangan potensi pariwisata baik dari ranah insfraktruktur, dan hospitality juga harus di lakukan. Jika bukan masyarakat lokal yang memanfaatkannya, tentu para investor asinglah yang kemudian memanfaatkan moment ini.

\section{Simpulan}

Berdasarkan analisis yang peneliti lakukan, dapat diambil beberapa kesimpulan bahwa berbagai strategi manajemen krisis yang dilakukan pemerintah mampu memberikan hasil nyata. Indikator hal tersebut adalah, banyak masyarakat yang sudah menerima kebijakan pemerintah untuk merelokasi pemukiman masyarakat, ataupun 
pembayaran ganti rugi. Sekarang ini, hanya tinggal sedikit saja kelompok masyarakat yang masih memilih untuk bertahan dan menolak direlokasi. Inilah tugas pemerintah selanjutnya, untuk bisa menyakinkan masyarakat yang masih menolak pembangunan bandara baru tersebut.

Selain itu, telah adanya upaya pemanfaatan media komunikasi oleh pemerintah untuk membangun komunikasi dua arah dengan masyarakat. Media komunikasi tersebut, dalam bentuk sosial media, website, maupun pembentukan media center. Media komunikasi tersebut, dimaksudkan untuk publikasi pemberitaan progress pembangunan bandara baru di Kulon Progo. Sehingga akan adanya dukungan dari masyarakat luas, terhadap rencana pembangunan bandara baru ini. Kemudian, tantangan manajemen krisis yang dilakukan pemerintah, sekarang ini adalah pada masyarakat yang masih menolak rencana pembangunan bandara baru ini. Pemerintah harus segera memberikan solusi bagi mereka agar proses pembangunan bandara baru dapat segera diselesaikan. Adanya kekhawatiran dari masyarakat, terhadap kelangsungan hidup mereka setelah berpindah tempat tinggal juga menjadi tantangan pemerintah untuk mencarikan solusinya. Pemerintah perlu membuat program-program pengembangan masyarakat, untuk memberikan keterampilan agar masyarakat mampu memperoleh mata pencaharian lain.

Adanya program pengembangan masyarakat untuk meningkatkan kesejahteraan mereka, menjadi harapan dari masyarakat. Berada di lingkungan baru tentu merupakan hal yang tidak mudah dilakukan oleh masyarakat. Mereka harus bisa beradaptasi dengan adanya dampak pembangunan bandara baru ini. Mendapatkan pekerjaan yang lebih baik, untuk bertahan hidup adalah keinginan mereka pasca menerima kebijakan relokasi pemukiman.

\section{Daftar Pustaka}

Fear-Banks, Kathleen. (2007). Crisis Communication: Planning Managing, and Responding. America: SAGE Publications.

Iriantara, Yosal. (2004). Community Relations. Bandung: Simbiosa.

Kasali. R. (2000). Manajemen Public Relations: Konsep dan Aplikasinya di Indonesia. PT Pustaka Utama Grafiti. Jakarta.

Newman, B.M. \& Newman P.R (2006). Development throught life: A psychosocial approach. $\left(9^{\text {th }} e d\right)$. United State of America: Thomson Wadsworth.

Regester, Michael, Judy Larkin. (2003). Risk Issues and Crisis Management in Public Relations. New Delhi: Crest Publishing House.

Smith, R. D. (2005). Strategy Planning for Public Relations 2nd Editions. Lawrence Erlbaum Associates.

Soemirat, Soleh dkk. (2008). Dasar-Dasar Public Relations. Bandung:PT Remaja Rosdakarya.

Watson, Hayley, Rachel L.Finn and Kush Wadhwa. (2016). Organizational and Societal Impacts of Big Data in Crisis Management. Journal of Contigencies and Crisis Management, Volume 25 Issue 1.

\section{Website :}

Konsep Pemberdayaan Bandara Kulon Progo Belum Siap. (2012). Tersedia dari: https:// ekbis.sindonews.com/read/670696/34/ konsep-pemberdayaan-bandarakulonprogo-belum-siap-1346944499 